\title{
Change and Stasis in the Iberian Middle Paleolithic
}

\author{
Considerations on the Significance of Mousterian \\ Technological Variability
}

\author{
by Ignacio de la Torre, Jorge Martínez-Moreno, and Rafael Mora
}

CA+ Online-Only Material: Supplements A and B

\begin{abstract}
The European Mousterian has traditionally been portrayed as a long period of technological stasis as opposed to the technotypological dynamism of Upper Paleolithic cultures. The classic debate on Mousterian variability explained interassemblage differences either by ethnic, cultural, functional, and chronological or by paleoenvironmental causes, but variability was based on typological considerations. Recently, technological factors have been introduced in discussions over time trends and geographic differences in the Mousterian. This paper will address the topic by reviewing technological strategies in the Iberian Middle Paleolithic. Three sites from northeastern Spain are chosen as a case study to address the existence of directional patterns in the Iberian Mousterian. We conclude that albeit diachronic variability exists, it does not show patterning, which suggests stochastic variation rather than directional change in the technological strategies of Iberian Neanderthals.
\end{abstract}

The notion of variability is at the heart of the study of the Mousterian. Spanning ca. $300 \mathrm{kyr}$ and present in hundreds of sites across western Europe, the search for explanations of interassemblage variability is consubstantial to Middle Paleolithic research. The classic debate on the interpretation of the Mousterian facies privileged cultural (Bordes 1972), functional (Binford 1973), diachronic (Mellars 1969), or climatic (Laville 1973) explanations, but it was strictly typological; that is, it was based on the assumption that Bordes's tool types were meaningful categories. Since the 1980s, the advent of technological approaches in Mousterian research (e.g., Boëda 1986; Geneste 1985) and the consideration of tool types as the result of different stages of reduction (Dibble 1987) led to explanations of most variability by raw material constraints and functional or settlement dynamics (e.g., Dibble and Rolland 1992). New attempts to understand the Mousterian facies from a functional perspective (e.g., Beyries 1988) and an in-

Ignacio de la Torre is Reader in Palaeolithic Archaeology at the Institute of Archaeology of University College London (31-34 Gordon Square, WC1H 0PY London, United Kingdom [i.torre@ ucl.ac.uk]). Jorge Martínez-Moreno is Research Associate and Rafael Mora is Professor of Prehistory at the Centre d'Estudis del Patrimoni Arqueologic de la Prehistoria of the Universitat Autónoma de Barcelona (Facultat de Lletres, 08193 Bellaterra, Spain). This paper was submitted 3 VII 13, accepted 27 VIII 13, and electronically published 20 XII 13. novative emphasis on the role of ecological factors in technological behavior (Kuhn 1995) added a novel dimension to the study of Middle Paleolithic variability.

In recent years, generalization of technological perspectives in most of western European Middle Paleolithic studies and the dramatic improvement of dating techniques for chronologies beyond the accelerator mass spectrometry (AMS) ${ }^{14} \mathrm{C}$ method have provided new tools to address the question of variability and time depth, now with an emphasis on the understanding of knapping techniques rather than tool types. Interest in evolution, stasis, and rhythms of change during the Middle Paleolithic (e.g., Kuhn and Hovers 2006) has shed new light in Neanderthal cultural adaptations, with pioneering studies focused on the technological characterization of Mousterian diachronic variability (Delagnes and Meignen 2006) and its functional/ecological correlation (Delagnes and Rendu 2011).

The aim of this paper is to apply some of these perspectives to the Mousterian of the Iberian Peninsula with the specific purpose of addressing the potential significance of diachronic patterns in lithic technology. A long history of research, abundance of karstic systems susceptible of preserving archaeological deposits, and relatively milder conditions than in most of Europe during the Pleistocene explains the substantial number of Mousterian sites known in Spain and Portugal. However, problems on the chronostratigraphic correlation of assemblages plus the variety of nomenclatures and analytical 
perspectives employed make it difficult to produce overall assessments such as those currently available for adjacent regions (Delagnes and Meignen 2006; Jaubert 2011) and the Near East (Goren-Inbar and Belfer-Cohen 1998; Hovers and Belfer-Cohen 2013).

In order to overcome the sample disparity derived from such methodological and empirical pitfalls, three Iberian sites excavated and studied within the same research program (Casanova et al. 2009; Martínez-Moreno et al. 2010; Mora et al. 2011) in the area of La Noguera (northeast Spain) are used in this paper to search for temporal trends in the Middle Paleolithic. Our results suggest that although diachronic variation is detected, it does not follow any particular pattern. This case study from La Noguera will then be discussed within the context of the Iberian Mousterian, in which a lack of time trends also prevails. Instead, the observed technological variability could be associated with intrasite specifics and, potentially, regional idiosyncrasies. This apparent lack of temporal patterns in the Iberian Middle Paleolithic contrasts with neighboring areas such as France, where chronological trends seem to exist (e.g., Delagnes and Meignen 2006). By combining different units of analysis (from particular case studies in northeast Spain to the regional scale of Iberia and to its contextualization within the sequence of southwestern Europe), the purpose of this paper is to contribute to the debate on technological change and stasis during the Middle Paleolithic and the nature and causes of Mousterian technological variability.

The Middle Paleolithic of La Noguera:

A Case Study on the Analysis of Technological Diachronic Patterns

Tragó, Roca dels Bous, and Cova Gran are three rockshelters in the region of La Noguera (Lleida, Catalunya) located within a radius of less than $20 \mathrm{~km}$ at the Marginal Exterior Sierras of the Eastern Pre-Pyrenees in the northeast of the Iberian Peninsula (CA+ Online Supplement A: fig. A1). Tragó has yielded eight archaeological levels, all attributed to the Mousterian. Thermoluminescence dating (CA+ Online Supplement B: table B1) situates the bottom layer (UA3) at approximately $126 \mathrm{kyr}$ and the uppermost (UA1) level of the main excavation area at ca. 42 kyr (Casanova et al. 2009). Ongoing excavations in Roca dels Bous have yet to reach the bedrock, and so far four main levels (R3, N10, N12, and N14) have been unearthed (Martínez-Moreno et al. 2010; Mora, de la Torre, and Martínez-Moreno 2004), all corresponding to the Mousterian. R3 was dated to $38.8 \pm 1.2 \mathrm{kyr}$, while underlying levels seem to be placed beyond the range of AMS ${ }^{14} \mathrm{C}$ (see table B1). Cova Gran is a huge $\left(>2,500 \mathrm{~m}^{2}\right)$ rockshelter with Upper Pleistocene and early Holocene deposits (Mora et al. 2011). Four Mousterian levels (S1B, S1C, S1D, and S1E) have been documented so far, situating Cova Gran among the most recent Middle Paleolithic sites in northern Iberia, perhaps as late as 33-32 kyr (Martínez-Moreno, Mora, and de la Torre 2010).

The three sites share a number of features enabling interassemblage comparisons. Both Roca dels Bous and Tragó are situated over two main river valleys that are natural corridors between the Ebro plain and the first ranges of the Pyrenees (fig. A1), while Cova Gran is located in a small subsidiary valley about $10 \mathrm{~km}$ north from Roca dels Bous. Pleistocene biotopes should have been similar in the three sites, with variations in the diversity of game according to climatic pulses but comparable density and availability of biotic resources. Availability of raw material was also similar; flint of poor quality is present in the immediate surroundings of Cova Gran and Tragó but not in the proximity of Roca dels Bous. Good quality flint was not locally available in any of the three sites. Quartzite and other metamorphic cobbles were readily available from river beds in the three sites, particularly in Roca dels Bous and Tragó.

In order to evaluate the possible existence of temporal trends, in this paper the Roca dels Bous (Martínez-Moreno, Mora, and de la Torre 2010; Mora, de la Torre, and MartínezMoreno 2004), Cova Gran (Martínez-Moreno, Mora, and de la Torre 2010), and Tragó (Casanova 2009) assemblages will be organized diachronically; Tragó levels cover oxygen isotope stage (OIS) 5e (UA3), OIS 5/4 (UA2), and OIS 3 (UA1). Roca dels Bous levels are probably within the same chronological range as UA1, but for the sake of comparison, N12 and N10 have been placed after the sequence of Tragó. Cova Gran levels S1D, S1C, and S1B have yielded consistent dates post $40 \mathrm{kyr}$ and therefore are considered here to belong to the latter part of OIS 3.

The artefacts $(N=59,001)$ analyzed from the three sites are distributed unevenly, with 23,557 lithics from Tragó, 19,569 from Roca dels Bous, and 15,875 from Cova Gran $(\mathrm{CA}+$ Supplement B: table B2). Relative frequencies of main stone tool types are shown in figure 1 . The percentage of cores does not indicate any clear patterning; while cores are consistently less abundant in Cova Gran than in the two older sites, N10 at Roca dels Bous yields the highest proportion of cores of all levels. Therefore, the comparative paucity of cores in the Cova Gran levels is better explained by site-specific economic variables rather than by temporal trends. In contrast, frequency of flakes seems to decrease steadily throughout the sequence, with the exception of S1C in Cova Gran (fig. 1B). The meaning of such consistent reduction on the frequency of flakes is obscure and could tentatively be related to recurrent export of flakes off site. A divide seems to exist in the sequence with regard to the frequency of retouched tools; while the four older assemblages yield very low frequencies, all levels from N10 to S1B contain percentages of retouched tools over $7 \%$ (fig. $1 C$ ). Even though no cumulative increase is observed across the four younger levels, the fact that a higher frequency of retouched tools is present in two sites (Roca dels Bous and Cova Gran) rules out the possibility 


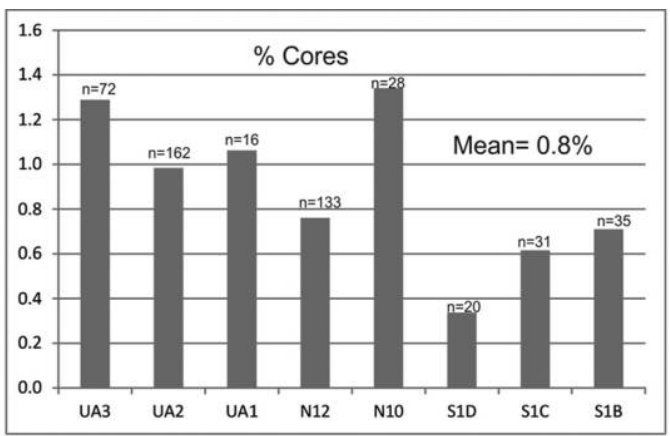

A)

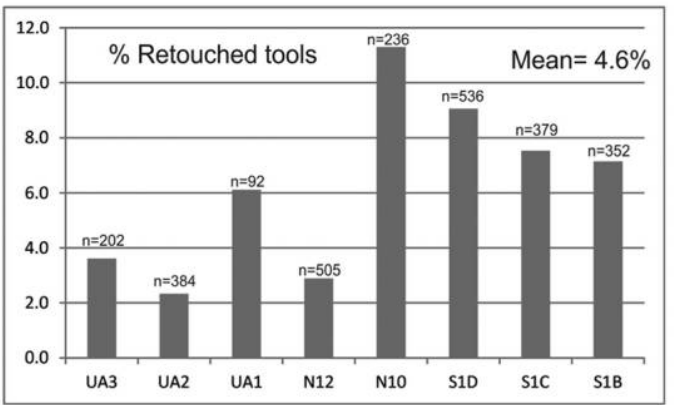

C)

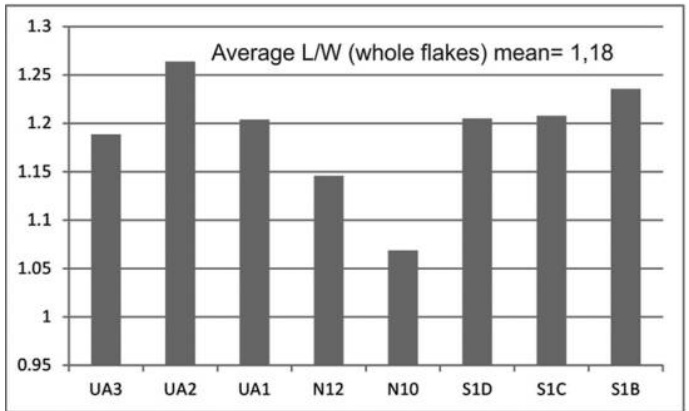

E)

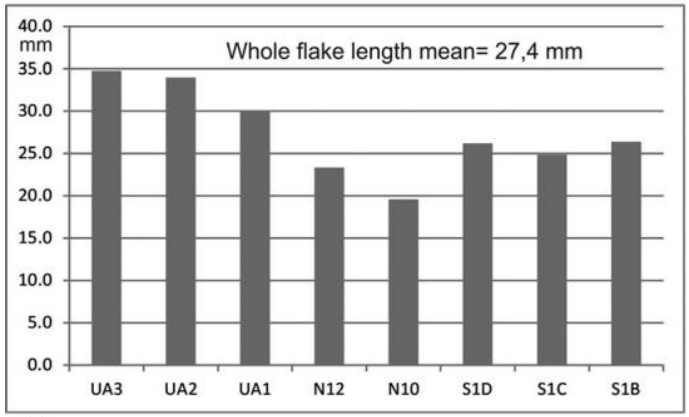

G)

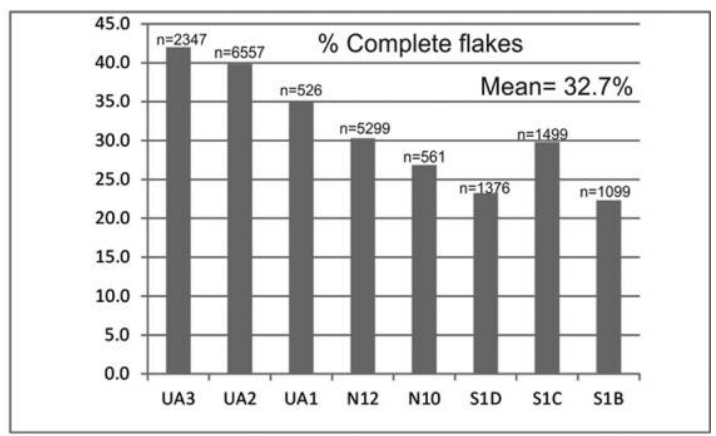

B)

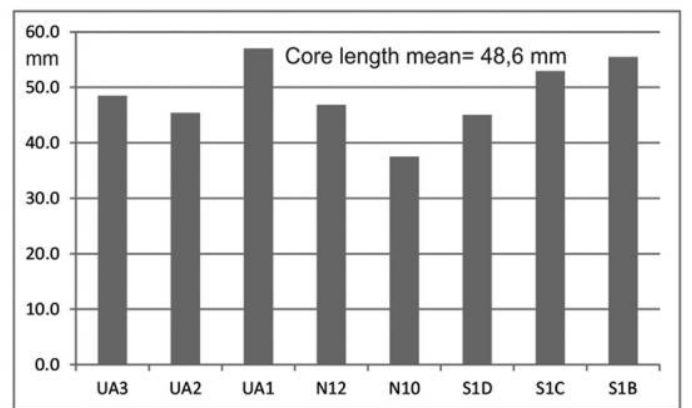

D)

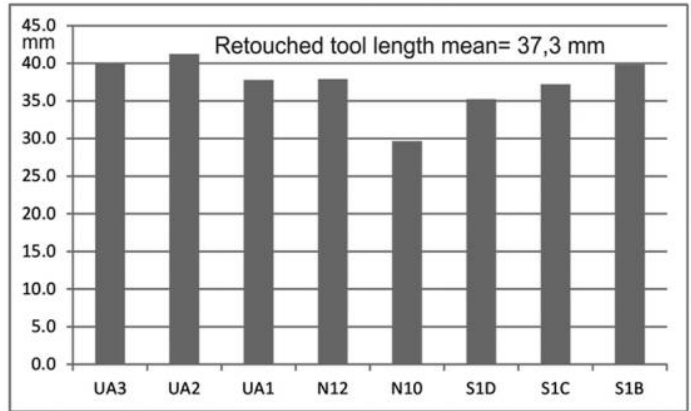

F)

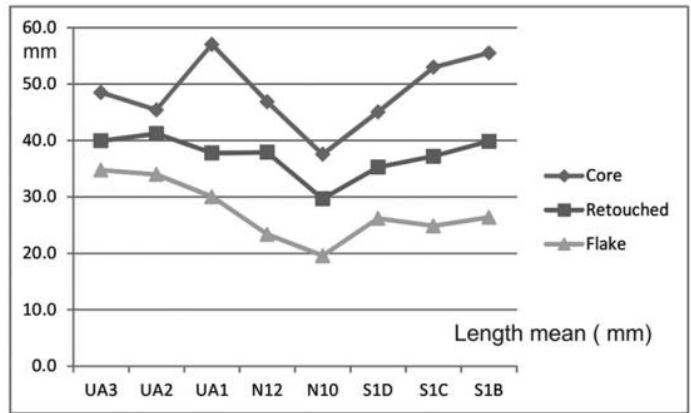

H)

Figure 1. Frequency and size of main categories in Tragó (Ua3, Ua2, Ua1), Roca dels Bous (N12, N10), and Cova Gran (S1D, S1C, S1B). A, Percentage of cores. B, Percentage of whole flakes. $C$, Percentage of retouched tools. $D$, Average length of cores. E, Elongation (length divided by width) of whole flakes. $F$, Mean length of retouched tools. $G$, Mean length of whole flakes. $H$, Average length of cores, whole flakes, and retouched tools. All data from CA+ Online Supplement B: table B2. A color version of this figure is available in the online edition of Current Anthropology. 
that this pattern was site-specific and could suggest some intensification in the shaping of blanks among latest PrePyrenean Neanderthals.

Metric analysis of the main categories (fig. 1; CA+ Supplement B: table B3) reflects consistency on lithic dimensions throughout the sequence. Average length of cores and retouched tools is remarkably similar from UA3 to S1B (fig. $1 D, 1 F)$, and even though flakes are larger in the oldest assemblages (fig. $1 G$ ), the length/width ratio (fig. 1E) of Tragó flakes resembles that of Cova Gran, which yields the most recent layers. The widely documented pattern of larger blank selection for retouching during the Mousterian (e.g., Dibble and Rolland 1992; Geneste 1985) is also verified in each and every one of the assemblages analyzed here, which show consistent larger size of retouched tools over unmodified blanks.

In general, data from figure 1 (see also table B3) do not indicate any kind of temporal trend but rather remarkably homogeneous size range for the main lithic categories across all assemblages. The only possible divergence is shown by $\mathrm{N} 10$ at Roca dels Bous, whose cores and flakes are noticeably smaller than those in the rest of the levels. However, the shortterm nature of this occupation (Martínez-Moreno, Mora, and de la Torre 2004; Mora, de la Torre, and Martínez-Moreno 2004) rather than any chronological pattern explains particularities of N10 more satisfactorily.

In order to explore the possible presence/existence of diachronic patterns on knapping methods, nearly 500 cores were considered in our analysis (CA + Supplement B: table B4). Levallois cores are poorly represented, with only N12 and S1C yielding relevant percentages. Bifacial hierarchical centripetal (sensu Casanova et al. 2009; de la Torre and Mora 2004) and unifacial methods are the most common in several assemblages, whereas discoid cores sensu stricto are rare. Figure $2 A$ suggests that neither Levallois nor any other flaking methods show temporal trends. To avoid subjectivities derived from flaking methods classification, a comparison (fig. 2B) was made between expedient cores-those that bear only a few scars (e.g., unifacial) and which underwent limited and/ or unstandardized (e.g., multifacial) reduction-versus structured cores-those including several stages of preparation and/or production (e.g., Levallois, bifacial hierarchical centripetal and discoid). Albeit expedient methods are rarely mentioned in the literature, they are common in the PrePyrenean Mousterian and indicate opportunistic reduction of part of the raw material stocks. However, once again no temporal pattern is discerned in the variation between expedient and structured methods: while structured methods tend to prevail (as expected from any Mousterian assemblage), expedient flaking is common at the beginning (UA3), middle (N10), and end (S1B) of the sequence.

Low variability of retouched tool types is well attested across the northeastern Iberian Mousterian sites (Mora 1988) and is confirmed in the Pre-Pyrenees sequence. Figure $2 C$ shows that sidescrapers and denticulates predominate, while points, endscrapers, and other retouched tools are represented resid- ually (see also CA+ Supplement B: table B5). There seem to be some differences between Tragó and the other two sites; while in Tragó nearly all shaped tools are either denticulates or sidescrapers, both in Roca dels Bous and Cova Gran, higher typological variability is attested, with points, endscrapers, and other tool types present in all levels. Tragó also consistently yields higher proportions of sidescrapers than Roca dels Bous and Cova Gran. However, it is unclear whether such a pattern responds to temporal trends or whether it could be explained instead by settlement dynamics specific to the earlier site of Tragó.

It remains to assess the role of raw materials in discerning potential time trends. Figure $2 D$ suggests an overall preference for flint across the sequence in all levels apart from N12. Interestingly, the four more recent layers show clear preference for flint, whereas the earlier assemblages of Tragó yield a more mixed procurement of flint and quartzite (see also CA + Supplement B: table B6). However, the exception of N12 in Roca dels Bous, where the raw material procurement strategy is completely reversed to that of the later levels, precludes establishing a clear diachronic pattern throughout the assemblages. The same applies to lithic categories with particular technological relevance; figure $2 E$ indicates that with the exception of N12, flint cores prevail in all assemblages. Similarly, flint was more often selected for structured knapping than quartzite. No temporal trend can be observed, either, in the selection of raw material for retouched tools; while the younger levels of Cova Gran reflect a strong preference for flint over quartzite, such preferential selection is exacerbated in UA1 at Tragó, one of the earlier assemblages. Although quartzite retouched tools in $\mathrm{N} 12$ are more abundant than flint in absolute terms, flint was preferentially used for retouching, which is consistent with the pattern observed in the rest of the sequence (fig. $2 F$ ).

\section{Chronological Patterns of the Iberian Middle Paleolithic}

Although better known for putatively yielding the last $\mathrm{Ne}$ anderthal traces anywhere in Europe (e.g., Finlayson et al 2006; Zilhão 2008), the Iberian record also contains a number of Middle and early Upper Pleistocene sequences. In principle, this should provide the time depth required to evaluate diachronic trends in the Iberian Mousterian. Unfortunately, the wealth of Middle Paleolithic sites in Iberia (fig. 3) is not accompanied by a solid chronostratigraphic framework; in recent years, research agendas have targeted dating of the last Mousterian and the transition to the Upper Paleolithic (d'Errico and Sánchez-Goñi 2003; Maroto et al 2012; Martínez-Moreno, Mora, and de la Torre 2010; Zilhão 2006), whereas older sequences are poorly constrained or simply lack any radiometric dating. Thus, figure 4 must be seen as a very preliminary attempt to order chronologically some of the relevant sites in the Iberian Mousterian. 


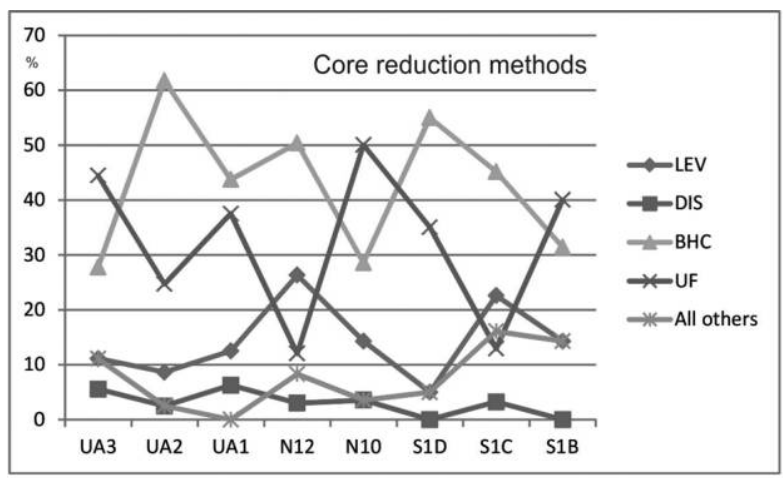

A)

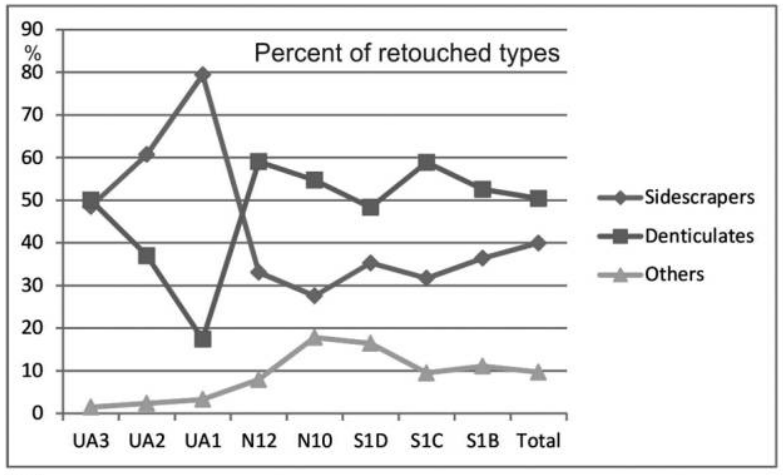

C)

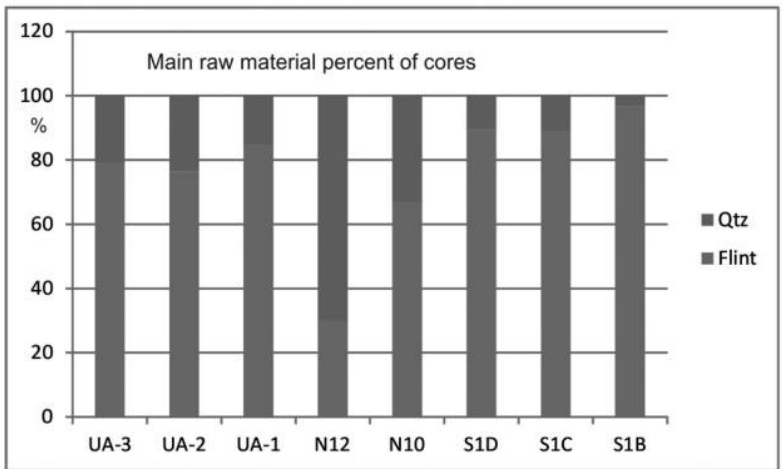

E)

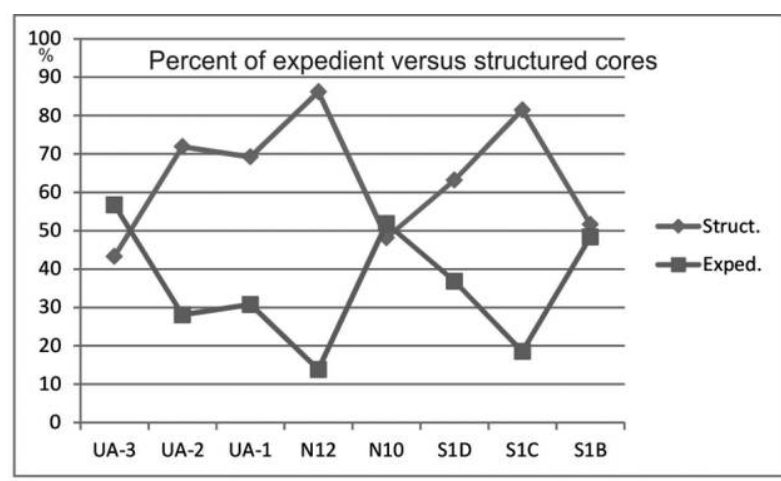

B)

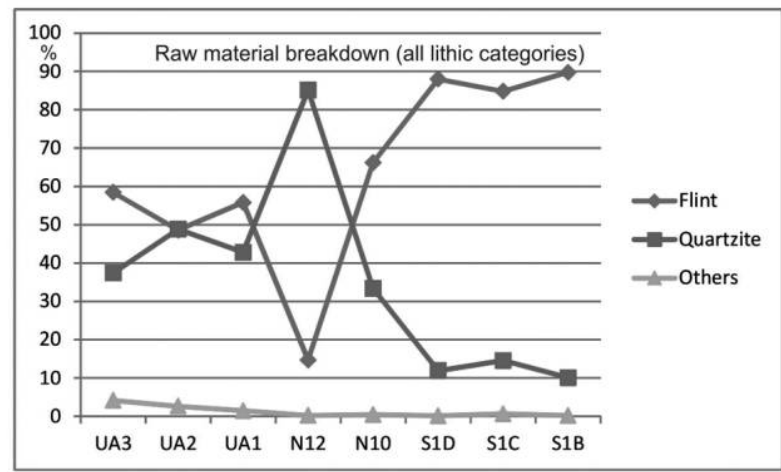

D)

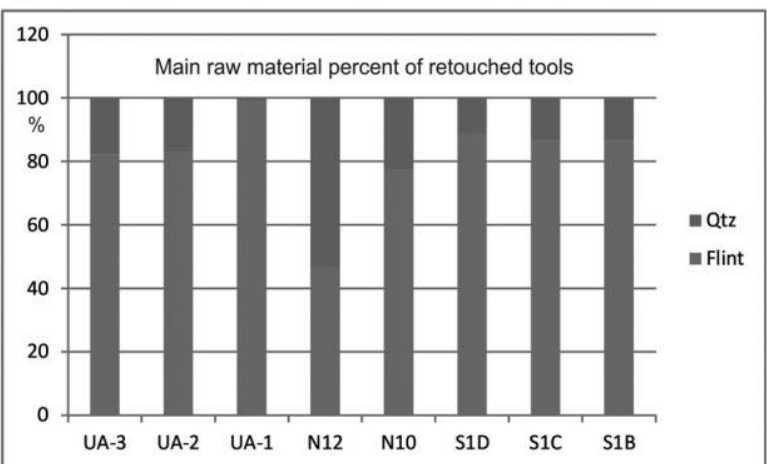

F)

Figure 2. Temporal trends in the technology and raw materials of Tragó, Roca dels Bous, and Cova Gran. LEV = Levallois; DIS = discoid; $\mathrm{BHC}=$ bifacial hierarchical centripetal; $\mathrm{UF}=$ unifacial; $\mathrm{MF}=$ multifacial. $A$, Relative frequency of main core reduction methods. $B$, Relative frequency of structured (LEV, BHC, DIS) versus expedient (bipolar, MF, UF) reduction methods. $C$, Relative frequency of main retouched types. All data from CA+ Online Supplement B: tables B4, B5. D, Breakdown of raw materials per assemblage. $E$, Raw material breakdown of quartzite and flint cores. $F$, Raw material breakdown of quartzite and flint retouched tools. All data from CA+ Online Supplement B: table B6. A color version of this figure is available in the online edition of Current Anthropology.

The level TD 10.1 at Atapuerca, dated to $337 \pm 29 \mathrm{kyr}$, could represent the earliest evidence of Middle Paleolithic technology in Iberia (Rodríguez 2004). Its large lithic and fossil assemblage shares some elements of continuity with the Acheulean (e.g., handaxes), but cores and retouched flakes indicate more standardized systems typical of the Mousterian (Ollé et al 2013). Cueva Horá and Cueva del Ángel, both in southern Spain, may potentially contain very old Mousterian assemblages, but a robust radiometric frame has yet to be developed. At present, the best documented cultural succession for the latter part of the Middle Pleistocene is that from Bolomor, in eastern Spain. Here, radiometric dates bracket between OIS 9 and OIS 5e more than a dozen archaeological units in which denticulate and sidescraper-rich layers alternate and no handaxes are recorded (Fernández-Peris 2007). The earliest levels of Bolomor (XVII-XV) are positioned between 


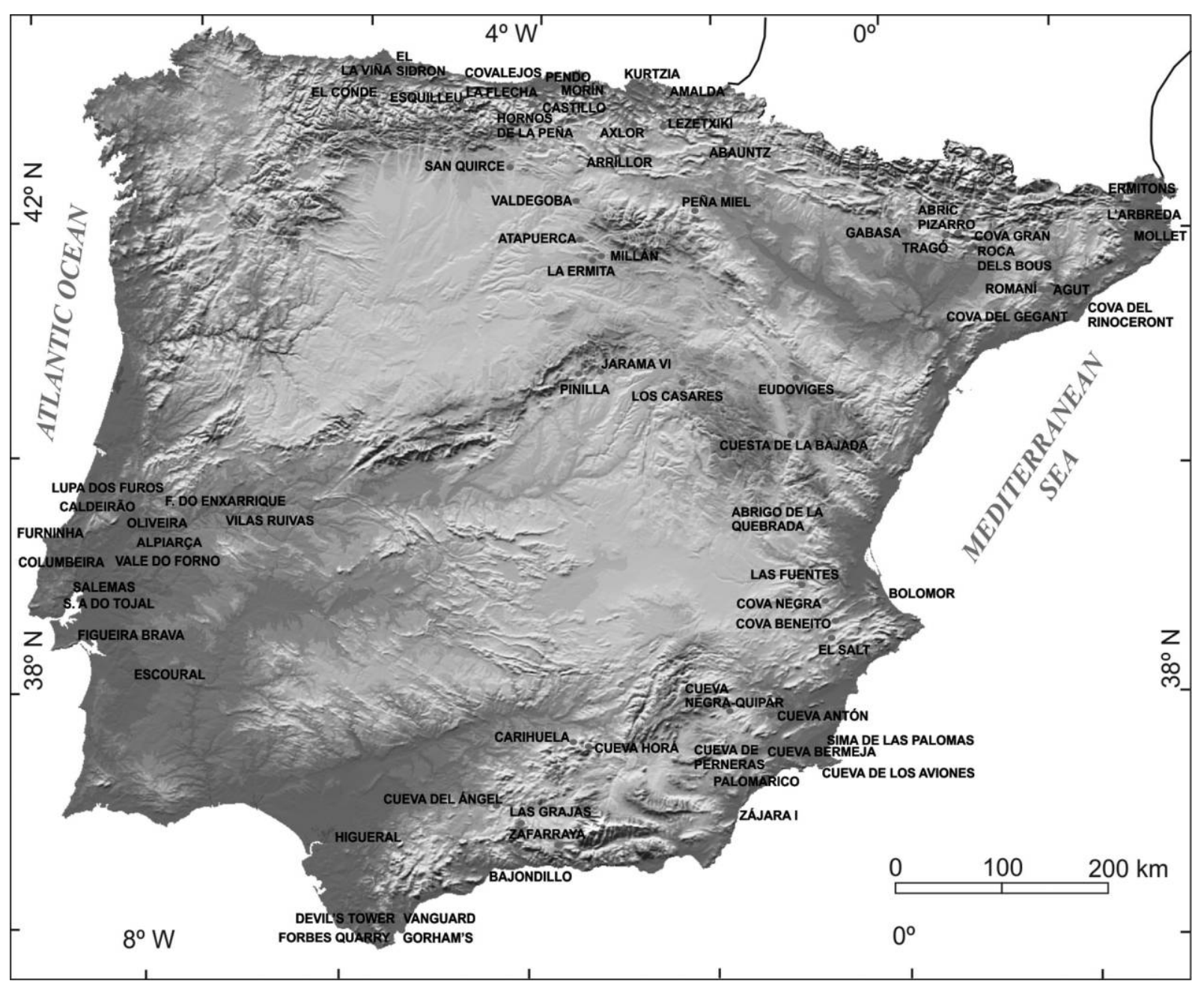

Figure 3. Geographic locations of the main Middle Paleolithic sites in Iberia. A color version of this figure is available in the online edition of Current Anthropology.

347 and $242 \mathrm{kyr}$ and are considered as early Middle Paleolithic (Fernández-Peris et al. 2008), which is in agreement with data from Atapuerca TD 10.1.

Both the Bolomor sequence and Atapuerca TD 10.1 point to an emergence of the Middle Paleolithic earlier than 300,000 BP. This would be in agreement with Mousterian-like features seen in late Acheulean open-air sites such as Ambrona AS6, dated over $350 \mathrm{kyr}$ (Santonja and Villa 2006), but it is at odds with the chronology of other late Acheulean sites in the Manzanares (e.g., Arriaga, Oxígeno), Guadiana, and Duero valleys, for which terminal Middle Pleistocene ages have been proposed. This calls for either a long coexistence of Acheulean and Mousterian technologies between 300 and 100 kyr, a gradual disappearance of handaxes in early Middle Paleolithic sequences as recorded elsewhere (e.g., Moncel et al 2011), and/or for a need to reconsider the chronology of some of the central Iberia terraces, which is in reality poorly constrained.
Other pre-OIS 5e sequences in caves/rockshelters present similar dating problems. Lezetxiki in northern Spain has yielded dates $>240$ kyr for level VII (Falguères, Yokoyama, and Arrizabalaga 2005), but most of the other radiometric ages are inconsistent. Cueva de los Aviones, Cueva de las Grajas, and Cueva Horá, all in the southern half of Spain, contain Mousterian (and in the case of Cueva Horá also Acheulean) layers attributed to the Middle Pleistocene, but no reliable radiometric dates have been published. It is likely that several other caves from figure 4 contain pre-OIS $5 \mathrm{e}$ Mousterian deposits, but at present, apart from Bolomor, only a few yield radiometric dates. Two of those caves are Carihuela and Tragó (southern and northeastern Spain, respectively); lower deposits from Carihuela range between 146 and 117 kyr (Vega et al. 1997) and show clear Mousterian features, while the bottom of the Middle Paleolithic sequence in Tragó is radiometrically dated to the beginning of the last interglacial (Casanova et al. 2009). 


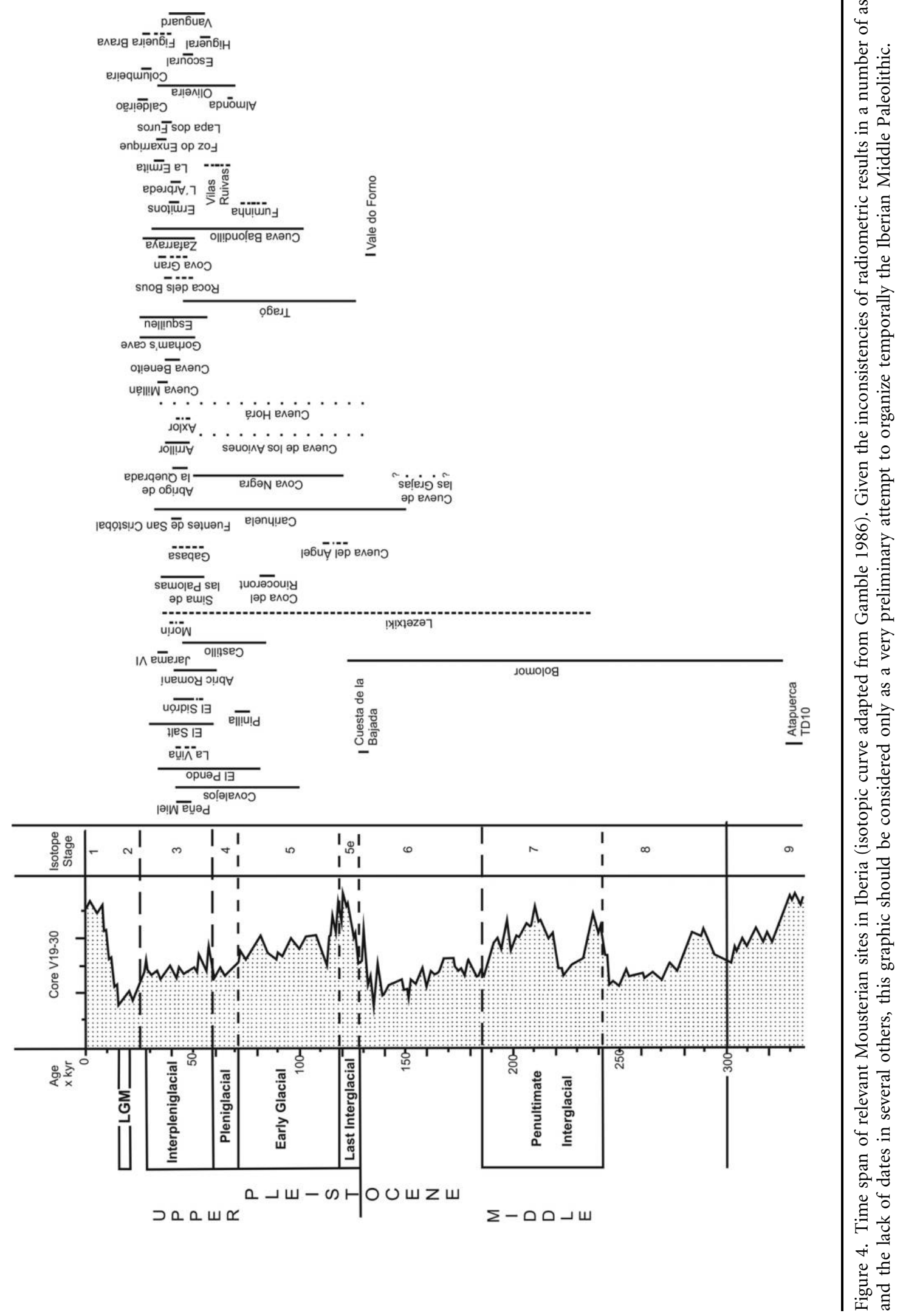


Figure 4 could lead us to believe that the majority of Iberian cave sites have no Mousterian occupation for most of OIS 5. However, that is likely to be an artefact of dating methods (in many sites no techniques other that ${ }^{14} \mathrm{C}$ have been attempted), and research program contingencies (often the bottom of stratigraphy has not yet been reached, and lower, unreported levels might be present). Focusing on the few sites for which OIS 5 levels are published, some of those already mentioned contain Early Glacial deposits, and several others can also be considered (see fig. 4). Among the latter, El Castillo and Cova Negra have yielded relatively consistent radiometric dates across thick sequences; in El Castillo, the classic Mousterian is capped between $70 \mathrm{kyr}$ (the age of level 22) and 39 kyr (dating proposed for the Early Aurignacian of level 18; Rink et al. 1997). Cova Negra contains a thick Mousterian stratigraphy spanning the whole of the Early Glacial (OIS $5 \mathrm{~d}-\mathrm{a}$ ), OIS 4, and part of OIS 3. Although radiometrically not as robust as Cova Negra, the Mousterian sequence of Cueva Bajondillo is also constrained between OIS 5 and OIS 3 (Cortés Sánchez et al. 2007), and so is the thick stratigraphy of Covalejos, dated between 100 and $40 \mathrm{kyr}$ (Montes and Sanguino 2005), and Oliveira, dated between $>70$ and $35 \mathrm{kyr}$ (Angelucci and Zilhão 2009).

According to the available dates, most of Mousterian sites in Iberia would correspond to the latest part of the Middle Paleolithic. While the possibility of a sudden proliferation of Neanderthal sites after $45 \mathrm{kyr}$ cannot be excluded, it is also very likely that the radiocarbon dating threshold rather than an actual gap in the archaeological record explains the absence of longer spans in the OIS 3 assemblages plotted in figure 4 . Similarly, the very recent radiocarbon dates obtained in a number of Iberian sites may be due to problems of the limits of AMS ${ }^{14} \mathrm{C}$; therefore, many of the late Mousterian dates from Iberian sites could be seen as minimum ages (e.g., Martínez-Moreno, Mora, and de la Torre 2010).

Leaving aside chronometric problems, the Iberian record contains some firmly dated sequences that account for continuous occupation throughout the first half of OIS 3. Probably the most outstanding is Abric Romaní, which yields wellconstrained Mousterian levels between 60 and $40 \mathrm{kyr}$ (Bischoff, Julià, and Mora 1988). Apart from several of the sites mentioned above, Esquilleu, El Salt, Vanguard Cave, and a few others (see fig. 4) also yield levels $>45$ kyr overlaid by late Mousterian assemblages. They all attest to thick sequences of Middle Paleolithic and, in principle, should enable assessing diachronic patterns in Mousterian technology, as discussed in the following section.

\section{Technological Trends in the Mousterian of Iberia}

If chronostratigraphic correlations are weak because of a lack of radiometric dates (especially for levels beyond the range of AMS ${ }^{14} \mathrm{C}$ ), interassemblage comparisons of the Iberian
Mousterian become even more difficult for several other reasons. First, many of the classic studies of the Iberian Middle Paleolithic were conducted within the typological approach, and therefore technological data are only available from recent publications. Even when technological studies are available, there is a focus on the late Mousterian and its comparison with the early Upper Paleolithic. In consequence, available information is biased to the detriment of older, pre-OIS 3 Mousterian assemblages, for which technological data are often very scarce. There is also a tendency toward qualitative descriptions against quantitative data that sometimes makes statistical comparisons unfeasible. More importantly, there is a generalized lack of consistency on the methodology employed to classify knapping methods and technological patterns; different conceptions exist on the meaning of discoid, Levallois, other centripetal cores, expedient flaking, and so forth, and therefore similar reduction methods are named with different terms. The opposite also occurs, with terms such as "discoid" used to classify cores that could be considered as recurrent Levallois or alike according to recent technological conceptions. All of this makes it difficult to contextualize the Pre-Pyrenean diachronic patterns within the Iberian Middle Paleolithic sequence and constrains the number of case studies that provide comparable data. Furthermore, available data from other case studies elsewhere in Iberia do not necessarily comprehend every technological aspect, which precludes a unified assessment of all analytical criteria (e.g., raw material selection, tool types, core reduction techniques, etc.) across the Iberian chronostratigraphic sequence. Hence, the patchy character of the available data determines the comparisons below, which are built on a composite view of a number of Iberian case studies.

At present, typological classifications of the Iberian Middle Paleolithic are unusual, and so the Bordesian taxonomy of table 1 is limited to data from some 1960s-1980s studies. As expected, no diachronic patterns are observed in the variation of Mousterian facies; in Cova Negra, one of the few dated Middle Paleolithic sequences, Quina-type Charentian was recognized at the bottom (level XIV: OIS 5d-b) and middle (XIII-XII, X-IX, VII-VI: OIS 4) of the stratigraphy, and the same occurs with the para-Charentian/typical Mousterian, identified both in OIS 4 (level XI, VIII) and at the beginning of OIS 3 (Villaverde 1984). While Cova Negra can be used as an instance of nondirectional temporal variability of Mousterian facies, Axlor provides an example of homogeneity of tool types through time; here, all levels are classified as typical or Quina Charentian (Baldeón 1999) despite the thick stratigraphy of the rockshelter. Despite reservations derived from the absence of radiometric dates, Axlor and several other sequences from table 1 can be placed at the onset of OIS 3 (see fig. 4). Given the variety of Mousterian facies represented in this time interval, it may be concluded that no temporal patterning exists.

The relative typological homogeneity of the Iberian Mousterian in comparison with the neighboring sequence of France 
Table 1. Mousterian facies in some classic Spanish assemblages

\begin{tabular}{|c|c|c|c|c|}
\hline Denticulate Mousterian & Charentian & Typical Mousterian & MTA & Mousterian with cleavers \\
\hline $\begin{array}{l}\text { Conde } 6 \\
\text { Morín 17b2, 11-5 } \\
\text { La Flecha } \\
\text { Pendo } 4 \\
\text { Romaní }\end{array}$ & $\begin{array}{l}\text { Castillo Beta (level 22) } \\
\text { Hornos de la Peña } \\
\text { Zájara } \\
\text { Cova Negra XIV-XII } \\
\text { Cova Negra X-IX } \\
\text { Cova Negra VII-VI } \\
\text { Lezetxiki IV } \\
\text { Peña Miel } \\
\text { Cueva Millán } \\
\text { La Ermita } \\
\text { Morín 12 } \\
\text { Pendo 5 } \\
\text { Axlor } \\
\text { Ermita } \\
\text { Eudoviges }\end{array}$ & $\begin{array}{l}\text { Casares } \\
\text { Cova Negra XI } \\
\text { Cova Negra IV-I } \\
\text { Lezetxiki VII-V } \\
\text { Amalda VII } \\
\text { Morín 17a-17b1, 16-13 } \\
\text { Pendo 12-6 } \\
\text { Mollet }\end{array}$ & $\begin{array}{l}\text { Cova Negra V } \\
\text { Abauntz }\end{array}$ & $\begin{array}{l}\text { Morín 13/14, 15-17 } \\
\text { Castillo Alfa (level 20) } \\
\text { Pendo XIII } \\
\text { Amalda } \\
\text { Lezetxiki V-VI } \\
\text { Gatzarria }\end{array}$ \\
\hline
\end{tabular}

Sources. Baldeón 1993, 1999; Butzer 1981; Cabrera 1984; Freeman 1966; Ripoll and de Lumley 1965; and Villaverde 1984.

Note. $\mathrm{MTA}=$ Mousterian of Acheulean tradition.

has sometimes been explained by limited availability of good raw materials in Spain and Portugal. While flint is ubiquitous around a number of sites in Andalusia and in some parts of the Mediterranean, quartzite and other metamorphic rocks predominate in large parts of western, central, and northern Iberia. Despite this unequal distribution of raw materials, we can discuss whether any diachronic patterns exist in the Middle Paleolithic procurement strategies. Again, data are not available for all assemblages, so here we selected case studies in which both raw materials and their availability in the landscape have been investigated (CA+ Supplement B: table B7). In the early Middle Paleolithic of TD 10.1, local flint is the predominant raw material, but a particular type of exotic flint is also documented for the first time in the Atapuerca sequence (Ollé et al. 2013), providing yet another element of differentiation between the previous Acheulean and TD 10.1. The thick sequence of Bolomor shows variations in raw material procurement (see fig. 5), but there seems to be no temporal patterning, and changes are related to climatic pulses during the Middle Pleistocene; small marine flint pebbles were preferentially selected when locally available during sea transgressions in detriment of other raw materials such as quartzite (accessible in the early part of the sequence) and especially limestone, an immediately available rock (Fernández Peris et al. 2008).

In the case of Abric Romaní, the location of raw material sources was more fixed, with flint available in a radius of 5$10 \mathrm{~km}$ and limestone and quartz in the immediate $(1 \mathrm{~km})$ surrounding of the rockshelter. Although from farther distances, flint was consistently preferred in most of the Romaní levels (Vaquero 1999). Raw material variation is documented throughout the sequence, but figure 5 shows no directionality toward any particular rock type. The Mousterian sequence from El Esquilleu probably spans more than $20 \mathrm{kyr}$, but substantial uniformity in raw material procurement is found across the levels (Manzano et al. 2005); percentage of quartz- ite, the most commonly used rock (table B7), varies throughout the sequence, but again no particular trend is observed (fig. 5). Most of the rocks were procured from a stream bed $200 \mathrm{~m}$ from the cave, and $99 \%$ of raw materials were found within a $5-\mathrm{km}$ radius (Manzano et al. 2005), although some stone tools are reported to come from more distant sources (Carrión et al. 2008).

Cova Gran and Tragó present an analogous pattern to the sites mentioned above; flint was readily available in Cova Gran and Tragó and consistently preferred in both sequences. The case of Tragó is particularly enlightening: UA3 and UA1 are ca. 80 kyr apart, and yet raw material procurement for each is remarkably similar (see table B7). Among the case studies selected for figure 5, only Roca dels Bous and Axlor suggest some divergence; in the case of Roca dels Bous, N10 presents opposite trends to N12 in the use of local (quartzite) versus imported (flint) rocks. However, the current lack of data for underlying levels makes it difficult to ascertain whether such reversal in the use of raw material was episodic or instead corresponds to a temporal trend in the sequence. With regard to Axlor, Ríos (2008) situates most of the flint sources between 15 and $30 \mathrm{~km}$ from the site, whereas other raw materialsuch as quartz, lutite, and so forth-were local $(<10 \mathrm{~km})$. Based on data from Baldeón (1999), it could then be stated that the sequence of Axlor sees a steady increase of exotic raw materials (fig. 5). This diachronic pattern could, potentially, be linked to increasingly larger foraging ranges and/or more demanding manufacture processes that required higher quality raw materials. Time trends have also been detected in some Portuguese Mousterian sites, but they point in the opposite direction; according to Zilhão (2001), in the sequence of Gruta da Oliveira, there is a steady decrease in the use of flint, and Gruta do Caldeirão shows a similar trend, which is related to mobility patterns focused on the exploitation of local quartzite sources.

With some exceptions (e.g., Ríos 2008; Vaquero et al. 2012), 


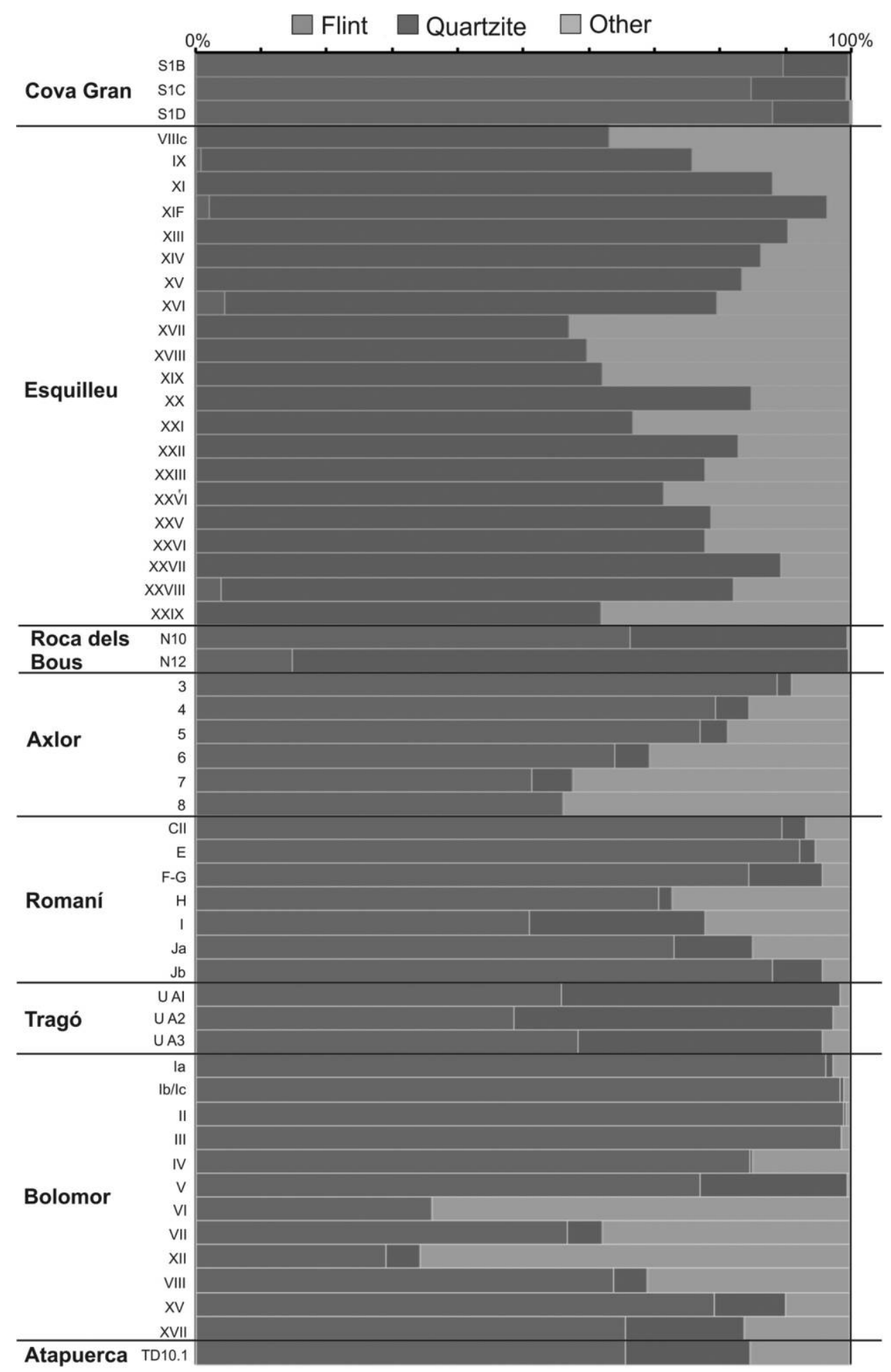

Figure 5. Raw material percentages in selected Iberian Middle Paleolithic assemblages. All data from CA+ Online Supplement B: table B7. A color version of this figure is available in the online edition of Current Anthropology. 
relationships between raw material procurement and other aspects of Neanderthal ecology (e.g., Geneste 1985; Kuhn 1995) are yet to be explored in the Iberian Middle Paleolithic, so it is not easy to assess the role of other subsistence activities in raw material acquisition and how specific foraging strategies may affect temporal patterns. Nonetheless, with this caution in mind, time trends seem to be an exception rather than the norm; most of the case studies discussed here show conservative patterns in the acquisition of raw materials, in which fluctuations do exist (not unexpectedly, for in several instances we are dealing with sequences spanning many thousands of years), but such variations may be explained by environmental constraints (e.g., Bolomor) or contingent settlement dynamics (Roca dels Bous, Romaní) rather than by directional trends toward local or exotic raw materials.

After excluding the existence of diachronic trends in typological and raw material patterns, we shall now discuss whether patterns in the variability of flaking methods can be traced. As mentioned above, this issue is particularly difficult to address; one reason is that disparity in the conceptions of Levallois, discoid, and other centripetal methods obscure potential interassemblage comparison of structured flaking methods. On the other hand, a fairly large number of available studies focus on such structured techniques, and simpler, more expedient flaking solutions are frequently excluded from the analysis. While consideration of Levallois and discoid becomes on occasion sophistic and might not help to discern general patterns (de la Torre 2009), differentiation between structured/long reduction sequences and expedient/short series cores (Casanova et al. 2009) may provide a more effective ground for time-depth comparisons. Such a comparative frame, nonetheless, is only available for a few sequences, so discussion will be restrained here to some particular case studies in which comparable technological data exist.

Discoid-like methods are known in Iberia since the Lower Pleistocene; Vaquero and Carbonell (2003) consider the recurrent bifacial centripetal method of Atapuerca TD 6 to be fairly similar to discoid flaking and report an increase of this technique throughout the sequence. According to Olle et al. (2013), centripetal strategies progressively become more standardized, leading to the Levallois-like technique from Upper TD 10.1 (OIS 9), in which morphometrical predetermination is observed. The roughly contemporary level XVII of Bolomor contains poor evidence of Levallois, while in upper levels such as XII-VII (OIS 6), hierarchization of cores (recurrent centripetal Levallois and/or hierarchical discoid) is attested (Fernández Peris et al. 2008). In OIS 5e, Bolomor levels VI-I contain discoid and Levallois flaking accompanied by trifacial and Kombewa cores (Fernández Peris et al. 2008). Tragó UA3, with a similar chronology, shows predominance of expedient methods followed by bifacial hierarchical centripetal (BHC) reduction, the latter being potentially similar to the recurrent bifacial centripetal method of Atapuerca (Vaquero and Carbonell 2003) and to many of the cores described as discoid and Levallois in Bolomor.
Most of the data on knapping systems correspond to OIS 4 and especially OIS 3. In the central Mediterranean region, Fernández-Peris et al. (2008) state that Mousterian assemblages of this chronology show predominance of Levallois as opposed to earlier periods. An example is the long sequence of El Salt, dated between 60 and $40 \mathrm{kyr}$, which shows prevalence of recurrent centripetal Levallois methods (Galván et al. 2006). A different pattern is reported in Cueva Bajondillo (southern Spain), where discoid flaking is better represented in the upper levels, albeit Levallois is common across the sequence (Cortés Sánchez 2008).

Detailed reports of flaking techniques are now available for a number of north Iberian OIS 4/3 assemblages. In Catalunya, discoid and discoid-like (e.g., BHC) methods are omnipresent in the Middle Paleolithic as opposed to lower frequencies of Levallois (Mora 1988). Although Cantabria follows a similar pattern, this region shows higher variability than Catalunya, which is probably explained by the larger number of sites documented. Carrión et al. (2008) state that although Levallois is not abundant, it is present in most of Cantabrian sites, usually in the recurrent centripetal modality. Discoid cores predominate and are often made on flakes (Carrión et al. 2008), and Kombewa flaking is also attested (e.g., Ríos 2008). Quina flaking is now identified in El Esquilleu (Carrión et al. 2008), Axlor, Gatzarri, Lezetxiki, and Amalda (Ríos 2008), but bearing in mind the recentness of the definition of this core reduction technique (Bourguignon 1997), it will be unsurprising if over the next few years Quina flaking is documented elsewhere. Bladelet production is suggested at Cueva Morín, El Castillo, and Covalejos (Bernaldo de Quirós, Sánchez-Fernández, and Maíllo 2010) within Mousterian levels where no traces of Upper Paleolithic are reported.

Indistinctive Quina and discoid flaking are documented in quartzite and flint, while Levallois is consistently made in the highest quality raw materials available (Carrión et al. 2008). Beyond recurrence of this pattern, and despite the wealth of Mousterian assemblages in the Cantabrian region, no clear correlations are yet available between knapping methods and other contextual elements. A particularly telling recent example illustrates the impenetrability of the meaning of flaking methods variability; at El Sidrón, the lithic assemblage was aimed at one very specific activity, that is, butchering other Neanderthals. Yet both discoid and Levallois cores were flaked in this single and task-specific event (Santamaría et al. 2010).

While acknowledging pitfalls derived from the disparity of core classification systems and chronometric problems of assemblages, we have compiled a few of the available case studies in order to assess diachronically north Iberia Mousterian knapping methods (CA+ Supplement B: table B8). Some sequences such as Gabasa indicate no change in primary flaking techniques. Abric Romaní does show diachronic patterning toward higher frequency of Levallois in the upper levels, whereas variations in El Esquilleu are nondirectional: discoid dominates the bottom and the top of the sequence, while Quina and Levallois methods are the commonest in some of 
the middle levels. Therefore, no clear patterns emerge from the diachronic assessment of intrasite variation.

With regard to intersite variability, figure 6 attempts to order chronologically the main flaking systems in the OIS 4OIS 3 case studies (see also table B8). Late OIS 4/early OIS 3 assemblages such as the lower levels of El Esquilleu, Abric Romaní, and (perhaps) Gabasa show predominance of discoid methods. If we were to assume that dates at the limit of the radiocarbon method are correct, then the trend would be more variable in the 45-39 kyr interval; Levallois predominates in El Castillo level 20e, top levels of Abric Romaní, Axlor N, and Arrillor level emj. Nonetheless, in a similar chronological span, discoid and discoid-like (e.g., BHC) techniques are the primarily flaking methods in Gabasa, Tragó UA1, Roca dels Bous level N12, and Morín levels 11 and 13, while Quina predominates in El Esquilleu levels XIII-XVI and Axlor B-D. The pattern is not clearer in post-39-kyr assemblages; Quina, Levallois, and discoid follow one another in the El Esquilleu top levels, while BHC flaking predominates in Cova Gran S1D-S1C and unifacial methods in Cova Gran S1B and Roca dels Bous N10. In short, figure 6 certifies for technical systems the same pattern (or rather, the lack of any) discussed above for typological facies and raw material procurement: an absence of directional changes or temporal trends.
Technological Variability of the Iberian Middle Paleolithic in the Context of Southwestern Europe

The case study of the Middle Paleolithic at La Noguera region has been presented above to examine possible time trends in the technology of the Iberian Mousterian. Our results suggest that albeit changes occur, they do not show directional patterns. Framing the three Pre-Pyrenean case studies within the wider context of the Iberian Mousterian, although hindered by methodological and empirical constraints, seems to suggest that the lack of diachronic patterning in technological strategies is applicable to most of the Portuguese and Spanish Middle Paleolithic. In truth, this is hardly surprising and comes to confirm on technological grounds what typological approaches (e.g., Bordes 1972) had long reported; that is, a substantial part of western European Middle Paleolithic assemblages show no defined time trends.

However, it is important to stress that absence of temporal directionality does not mean randomness of variation. Intrasite variability in Roca dels Bous (Martínez-Moreno, Mora, and de la Torre 2004; Mora, de la Torre, and Martínez-Moreno 2004), Bolomor (Fernández Peris 2007), Romaní (Vaquero 1999), Axlor (Ríos 2008), El Esquilleu (Baena et al. 2005), and others may respond to alternative settlement dynamics potentially related to distinct foraging strategies by Neander-

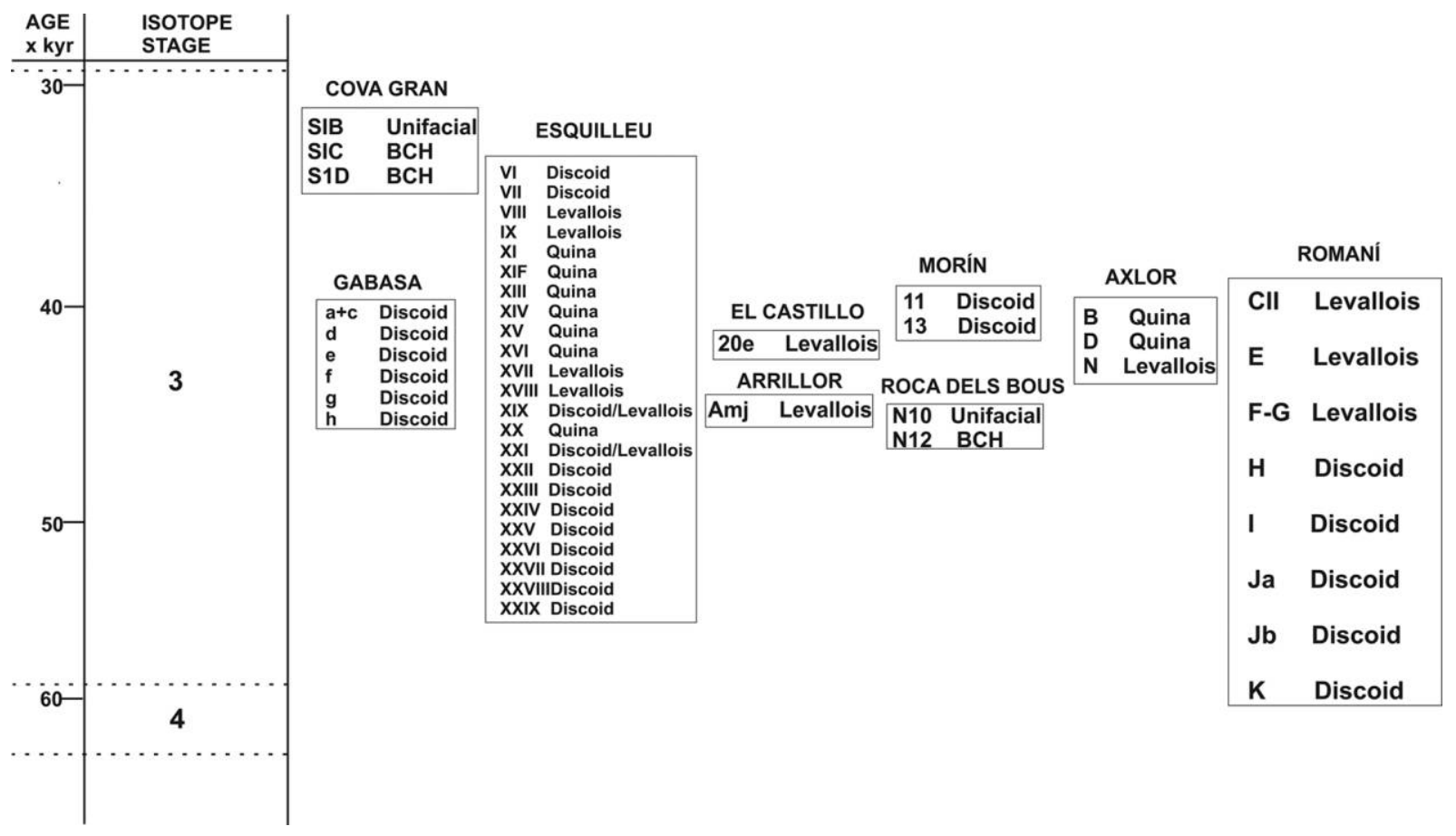

Figure 6. Chronostratigraphic position of flaking techniques in the OIS $4 / 3$ assemblages from CA+ Online Supplement B: table B8. 
thal groups. A challenge in current studies of intrasite variability is to decipher why changing technological behaviors are documented in contexts where raw material sources were fixed and biotic resources would have been similar through time; that will surely help explain the apparently random changes detected in some archaeological sequences.

Once methodological disparities are overcome and the serious chronometric problems are addressed, interassemblage comparisons may also play a more important role in modern analysis of Iberian Middle Paleolithic technological strategies and in the recognition of temporal trends. The Iberian record has the required time depth to explore more than $250 \mathrm{kyr}$ of Mousterian history, and it is unfortunate that substantial parts of this research focus only on the Neanderthal extinction interval. Also, the absence of time trends and the attribution of intrasite variability to contingent settlement strategies do not preclude the existence of other variables of differentiation in the Mousterian of Iberia with respect to the adjacent region of France and within Iberia itself. Traditionally attributed to raw material constraints, the scarcity of preferential flake Levallois cores in Iberia is noticeable; they certainly appear in some Middle Paleolithic sites, but they are much less common than Levallois recurrent centripetal methods. Predominance of recurrent centripetal techniques is a feature shared with the Mousterian of the Aquitaine basin, but while in the French sequence some evolution within Levallois methods is documented (Turq 2000), such variation is not identified in Iberia. Turq (2000) also reports numerous Kombewa flakes both for making handaxes and cleavers and as core blanks. While Kombewa is not yet much reported in Iberian assemblages, the role of flakes as cores is increasingly recognized; as detailed by Bourguignon, Faivre, and Turq (2004) across French sites, such "ramification" of chaînes opératoires may explain the remarkably small size of stone tools in some Mousterian assemblages from both the north (Ríos 2008) and south (Cortés Sánchez 2007) ends of the Iberian Peninsula. It is unlikely, however, that this so-called ramification explains all instances of small-sized assemblages, for in some cases, such as Cuesta de la Bajada (Santonja et al 2000) and Bolomor (Fernández Peris 2007), raw material constraints may be responsible, while in others (e.g., Roca dels Bous) the small size of artefacts is due to intentional extreme exhaustion of nodular cores (Mora, de la Torre, and Martínez-Moreno 2004).

Regional variability of tool types should also be investigated. In general, the diversity of retouched tools seems to be lower in Iberia than in southwestern France. Levallois and Mousterian points, backed knives, and others are present in a number of Iberian Mousterian sites but show even lower frequencies than in southwestern France. Sidescrapers dominate most Iberian sites apart from Catalunya and some Cantabrian sites, and such sidescraper-rich assemblages are often considered as "typical" Mousterian. Cantabria and Catalunya seem to present some idiosyncrasies. The presence of cleavers is well documented in some Cantabrian coast (El Castillo, Morín, Lezetxiki, Pendo, Amalda, and Gatzarria) and French
Pyrenees (Isturitz, Abri Olha, Calavanté, and Noisetier) Mousterian assemblages. Although subsequent studies (e.g., Cabrera, Pike-Tay, and Bernaldo de Quirós 2004; Freeman 1966) excluded Bordes's original proposal of the Vasconian as a distinct facies, new hypotheses (e.g., Thiébault et al. 2012) somehow rescue the original idea and propose a specific technological entity for the group of Mousterian sites with cleavers. Also, denticulates predominate in some Cantabrian and many Catalonian assemblages, which is not a common pattern elsewhere in Iberia. This prevalence of denticulate assemblages, especially in Catalonian sites, has been known for a long time (Mora 1988; Ripoll and de Lumley 1965) and has also recently been proposed as sharing traits with French Pyrenean assemblages (Thiébault et al. 2012). Albeit further correlations and interassemblage comparative work is required, these examples seem to suggest that regional variability in Iberia could exist.

For the moment, however, it is difficult to compare data directly on temporal and regional variation from Iberia with neighboring regions such as France. In the latter, the high density of sites, development of a reliable radiometric framework, and consistency of technological study and publication of site reports has enabled researchers to construct a solid chronostratigraphic sequence where time trends in technology can be evaluated more precisely. Technological reviews began in the wake of the 1960s-1980s typological debate on the meaning of Middle Paleolithic variability, and even in recent years (e.g., Delagnes, Jaubert, and Meignen 2007) attempts have been made to adequate the Mousterian facies to the currently prevalent technological reading of assemblages. Thus, a meaningful association is proposed to exist between the typological facies of La Ferrassie Mousterian and the Levallois method, the Denticulate Mousterian and discoid flaking, the Quina Mousterian facies and Quina reduction, and the typical Mousterian of Levallois facies and Levallois recurrent flaking (Delagnes, Jaubert, and Meignen 2007).

Since the beginning of the chaine opératoire approach in the 1980s, certain diachronic patterns in technology were discerned, particularly with regard to the evolution of the Levallois technique (Geneste 1990). In the Aquitaine basin, Turq (2000) reports a change from unidirectional and bidirectional recurrent Levallois in pre-OIS 5 assemblages to centripetal recurrent Levallois in Last Glacial sites. He also states that from OIS 5, centripetal methods dominated alongside Kombewa and Quina flaking. According to Delagnes and Meignen (2006), preferential Levallois is consistently older and commoner in the north than in southern France, and centripetal recurrent Levallois became dominant after OIS 5. The Rhone Valley (Moncel and Daujeard 2012) offers a different picture, however, in which Levallois is mostly centripetal during OIS 8 while unidirectional and bidirectional Levallois cores predominate in OIS 4 and 3. Actually, the OIS 8-OIS 3 sequence at the Rhone Valley (Moncel and Daujeard 2012:113) somewhat resembles the random variation of flaking systems and tool-type frequencies discussed above for Iberia, showing sto- 
chastic predominance of Levallois and discoid methods and nondirectional changes in the percentage of scrapers and points.

Other technological indicators may potentially bear clearer chronological meaning. In northern France, blade production is limited to the early OIS 5 (Delagnes and Meignen 2006) and does not appear in the Rhone Valley before the last interglacial, although in southeastern France, blade assemblages continues after the early OIS 5 (Moncel and Daujeard 2012). Blade and/or bladelet production seem also to be characteristic of some late Mousterian assemblages; elongated blanks in the southwestern France Mousterian of Acheulean tradition (MTA) could be a precursor for the Chatelperronian blade technology (Pelegrin and Soressi 2007), while in the southeast the Charentian would evolve into blade and bladelet industries with a marked regional character (Slimak 2008).

In summary, evidence seems to suggest that some time trends exist in the Middle Paleolithic technology of France. Recent overviews of the Aquitaine record report a succession of the predominance of flaking systems, with prevalence of Levallois and laminar reduction in the OIS 7-OIS 5 sites followed by Quina, MTA, and discoid/denticulate assemblages from OIS 4 until the transitional industries to the Upper Paleolithic (Delagnes and Rendu 2011). Changes within the MTA are also given a chronological significance, with MTA type A assemblages being consistently older than the MTA type B (Soressi 2004), and <50 kyr sites from southeast France are reported to undergo a process of microlithization and typological specialization (Slimak 2008).

Although the transitional industries to the Upper Paleolithic are beyond the scope of this paper, it is worth noting that most indicators of Mousterian variability in France are clustered in the later Middle Paleolithic. Delagnes and Meignen (2006) report higher diversification of flaking systems in later stages of the Mousterian in which production of blanks with a low degree of predetermination predominates. Idiosyncratic industries such as the MTA seem to be mostly constrained to post-50-kyr sequences (Soressi 2004), and a similar time trend applies to the appearance of new tool types and blade/bladelet production in the Rhone Valley (Slimak 2008). Therefore, there seems to be some kind of "shift of gear" that accelerates technological change in the $<50$-kyr Mousterian French sequence, resulting in a more conspicuous interassemblage variability. Such variability certainly bears chronological connotations, potentially regional differentiation, and putatively also cultural evolutionary implications, given the temporal proximity to the early Upper Paleolithic.

Causes of these general temporal trends have also been investigated. For example, recent studies have aimed to establish links between particular knapping systems and subsistence strategies, providing an explanatory cause for chronological patterns. But so far results are contradictory; assuming an association between flaking methods and mobility patterns, Delagnes and Rendu (2011) relate predominance of Levallois and blade production with low transport- ability of blanks and low mobility patterns, link the MTA with high mobility Neanderthal groups, and see discoid/denticulate-dominated assemblages as the result of multipurpose and highly versatile tool kits. Scott and Ashton (2011), however, propose for early Levallois assemblages exactly the opposite and consider that Levallois represents increased transport of blanks and extended curation. Likewise, whereas some propose that MTA bifaces were multipurpose tools (e.g., Soressi 2004), others see these as single-tasked artefacts related to butchery made by highly mobile Neanderthals (Delagnes and Rendu 2011).

Beyond interpretive problems of interassemblage variability, it remains clear that the French record contains a solid and reliable chronostratigraphic record and that such a record could indicate some kind of time patterning in Mousterian technology (Delagnes, Jaubert, and Meignen 2007; Delagnes and Meignen 2006; Delagnes and Rendu 2011). For the moment, such trends are particularly conspicuous in the later part of the Mousterian and could be related to a process of regionalization, particularly in the south of France (Slimak 2008). Regionalization phenomena are seen in adjacent regions of Europe at the end of the Middle Paleolithic not only on typological grounds but also according to technological indicators, such as in Italy (Kuhn 2006). However, this temporal trend has yet to be discerned in the Iberian Peninsula, where a number of challenges discussed in this paper confound any potential patterns. When compared with the neighboring area of France, the Iberian Middle Paleolithic record shows more technotypological homogeneity, both regionally and diachronically. In order to ascertain whether this lack of variability in the Iberian Mousterian is real or an artefact of empirical and methodological problems, further efforts are required to develop a chronostratigraphic and technological data set framework comparable with that available in other parts of western Europe and the Near East.

\section{Conclusions}

The debate on change versus stasis is inseparable from the assessment of Mousterian technology. Two questions can be asked here (Kuhn 2006). First, did major technological innovations occur during the Middle Paleolithic? Many would agree with Kuhn (2006) that the whole package of technological features documented in the latest Mousterian is already present during the early Middle Paleolithic. Second, and a different issue, does Mousterian variability shows directional trends? With some exceptions (e.g., Mellars 1969), the typological approach failed to detect such temporal patterns in the Middle Paleolithic repertoire.

In recent years, technological perspectives have also explored the existence of diachronic trends but from the view of the knapping systems. For example, Scott and Ashton (2011) argue that most of early Middle Paleolithic sites in Northern Europe show predominance of preferential Levallois methods that are not so conspicuous in later assemblages. In 
the same vein, laminar technologies are reported to be more common in earlier Middle Paleolithic assemblages (Bar-Yoser and Kuhn 1999). In general, the French sequence seems to present at the end of the Mousterian greater diversity of flaking methods coexisting at the same time and larger frequency of lower predetermination systems (Delagnes and Meignen 2006).

Can we apply such observations to the Iberian record? This paper has argued that according to the evidence currently available, time trends either do not exist or are not discernible because of a lack of comparable data. We acknowledge that the La Noguera Middle Paleolithic does not provide enough time depth and sufficient sites to build up a solid sample. It should also be remembered that chronostratigraphic and methodological problems are too acute to allow drawing firm conclusions on interassemblage correlations for the whole of Iberia. Therefore, this paper should be seen as an attempt to speculate about the diachronic potential of the Iberian Middle Paleolithic rather than a categorical exclusion of the existence of the time patterns documented elsewhere in western Europe. As stated in an earlier section, it would be unsurprising if such patterns are detected once the Iberian record is organized in a more reliable chronological framework and technological studies become readily available.

For now, however, directionality of assemblage variability is not visible in the Iberian Middle Paleolithic. Quoting Kuhn (2006:110), "While the Mousterian may have changed over time it was not going anywhere in particular," Iberia included. This does not mean that it is unworthy to keep trying to disentangle the long historical trajectory of the Mousterian As pointed out above, most of current efforts in Mousterian research in Spain and Portugal are privileging only the transition to the Upper Paleolithic. This is definitely not unique to Iberia, and it has been argued that also elsewhere "what is almost never addressed is what was going on earlier in the Middle Paleolithic, before modern humans and the Upper Paleolithic came on the scene" (Kuhn and Hovers 2006:3). Only further research can help to address this problem.

\section{Acknowledgments}

We thank Erella Hovers, Steven Kuhn, and Leslie Aiello for the invitation to participate in the "Alternative Pathways to Complexity" Wenner-Gren symposium and to contribute to this special issue of Current Anthropology. Comments by the guest editors and two anonymous reviewers on an earlier $\mathrm{draft}$ of this paper are gratefully acknowledged. Excavations in the Pre-Pyrenees Middle Paleolithic are funded by the Spanish Ministerio de Ciencia e Innovacion (HAR2010-15002). R. Mora is grateful for the support of the Institució Catalana de Recerca i Estudis Avançats.

\section{References Cited}

Angelucci, Diego E., and Joao Zilhão. 2009. Stratigraphy and formation processes of the Upper Pleistocene deposit at Gruta da Oliveira, Almonda Karstic System, Torres Novas, Portugal. Geoarchaeology 24:277-310.

Baena, Javier, E. Carrión, B. Ruiz, B. Ellwood, C. Sesé, J. Yravedra, J. Jordá, et al. 2005. Paleoecología y comportamiento humano durante el Pleistoceno Superior en la comarca de Liébana: la secuencia de la Cueva del Esquilleu, Occidente de Cantabria, España. In Neandertales cantábricos: estado de la cuestión. Jose A. Lasheras and Ramon Montes Barquín, eds. Pp. 461-487. Monografías Museo de Altamira 20. Madrid: Ministerio de Cultura, Subdirección General de Publicaciones, Información y Documentación.

Baldeón, Amelia. 1993. El yacimiento de Lezetxiki (Gipuzkoa, País Vasco): los niveles musterienses. Munibe 45:3-97.

. 1999. El abrigo de Axlor (Bizkaia, País Vasco): las industrias líticas de sus niveles Musterienses. Munibe 51:9-121.

Bar-Yosef, Ofer, and Steven L. Kuhn. 1999. The big deal about blades: laminar technologies and human evolution. American Anthropologist 10:322-338.

Bernaldo de Quirós, Federico, Granada Sánchez-Fernández, and Jose M. Maíllo. 2010. Technological characteristics at the end of the Mousterian in Cantabria: the El Cíastillo and Cueva Morín (Spain). In The Upper Palaeolithic revolution in global perspective: papers in honour of Sir Paul Mellars. Katherine V. Boyle, Clive Gamble, and Ofer Bar-Yosef, eds. Pp. 153-160. Cambridge: McDonald Institute.

Beyries, Sylvia. 1988. Functional variability of lithics sets in the Middle Paleolithic. In Upper Pleistocene prehistory of western Eurasia. Harold L. Dibble and Anta Montet-White, eds. Pp. 213-223. Philadelphia: University Museum, University of Philadelphia.

Binford, Lewis R. 1973. Interassemblage variability: the Mousterian and the functional argument. In The explanation of culture change: models in prehistory. Colin Renfrew, ed. Pp. 227-254. London: Duckworth.

Bischoff, James L., Ramon Julià, and Rafael Mora. 1988. Uranium series dating of the Mousterian occupation at Abric Romaní, Spain. Nature 332:68-70.

Boëda, Eric. 1986. Approche technologique du concept Levallois et évaluation de son champ d'application. PhD dissertation, Université Paris X Nanterre. Bordes, François. 1972. A tale of two caves. New York: Harper \& Row.

Bourguignon, Laurence. 1997. Le Moustérien de type Quina: nouvelle définition d'une entité technique. $\mathrm{PhD}$ dissertation, Université Paris X Nanterre.

Bourguignon, Laurence, Jean-Philippe Faivre, and A. Turq. 2004. Ramification des chaînes opératoires: une spécificité du Moustérien? Paléo 16:37-48.

Butzer, Karl W. 1981. Cave Sediments, Upper Pleistocene stratigraphy and Mousterian facies in Cantabrian Spain. Journal of Archaeological Science 8: 133-183.

Cabrera, Victoria. 1984. El yacimiento de la cueva de "El Castillo" (Puente Viesgo, Santander). Bibliotheca Praehistorica Hispana, vol. 22. Madrid: Consejo Superior de Investigaciones Científicas, Instituto Español de Prehistoria.

Cabrera, Victoria, A. Pike-Tay, and F. Bernaldo de Quirós. 2004. Trends in Middle Paleolithic settlement in Cantabrian Spain: the Late Mousterian at Castillo Cave. In Settlement dynamics of the Middle Paleolithic and Middle Stone Age, vol. 2. Nicholas J. Conard, ed. Pp. 437-460. Tübingen: Kerns.

Carrión, Elena, J. Baena, C. Conde, F. Cuartero, and M. Roca. 2008. Variabilidad tecnológica en el musteriense de Cantabria. In Variabilidad técnica del Paleolítico Medio en el sudoeste de Europa, vol. 14. Rafael Mora, Jorge Martínez-Moreno, Ignacio de la Torre, and Joel Casanova, eds. Pp. 279318. Barcelona: Treballs d'Arqueologia.

Casanova, Joel. 2009. Estrategias tecnológicas de los neandertales en la vertiente sur del Pirineo oriental. PhD dissertation, Universidad Autonoma de Barcelona.

Casanova, Joel, R. Mora, J. Martínez-Moreno, and I. de la Torre. 2009. Stratégies techniques dans le Paléolithique Moyen du sud-est des Pyrénées. L'Anthropologie 113:313-340.

Cortés Sánchez, Miguel, ed. 2007. Cueva Bajondillo (Torremolinos): secuencia cronocultural y paleoambiental del Cuaternario reciente en la Bahía de Málaga. Málaga: Diputación de Málaga.

. 2008. Variabilidad tecnológica en el Paleolítico Medio meridional ibérico: un punto de partida. In Variabilidad técnica del Paleolítico Medio en el sudoeste de Europa, vol. 14. Rafael Mora, Jorge Martínez-Moreno, Ignacio de la Torre, and Joel Casanova, eds. Pp. 105-119. Barcelona: Treballs d'Arqueologia.

Delagnes, Anne, Jacques Jaubert, and Liliane Meignen. 2007. Les technocomplexes du Paléolithique moyen en Europe occidentale dans leur cadre diachronique et géographique. In Les néandertaliens, biologie et cultures. Bernard 
Vandermeersch and Bruno Maureille, eds. Pp. 213-229. Paris: Editions du Comité des Travaux Historiques et Scientifiques.

Delagnes, Anne, and Liliane Meignen. 2006. Diversity of lithic production systems during the Middle Paleolithic in France: are there any chronological trends? In Transitions before the transition: evolution and stability in the Middle Paleolithic and Middle Stone Age. Erella Hovers and Steven. L. Kuhn, eds. Pp. 85-107. New York: Springer.

$\rightarrow$ Delagnes, Anne, and Will Rendu. 2011. Shifts in Neandertal mobility, technology and subsistence strategies in western France. Journal of Archaeological Science 38:1771-1783.

de la Torre, Ignacio. 2009. Technological Strategies in the Lower Pleistocene at Peninj (west of Lake Natron, Tanzania). In The cutting edge: new approaches to the archaeology of human origins. Kathy Schick and Nicholas Toth, eds. Pp. 93-113. Bloomington, IN: Stone Age Institute.

de la Torre, Ignacio, and Rafael Mora. 2004. El Olduvayense de la sección tipo de Peninj (Lago Natron, Tanzania). Monografies del CEPAP 1. Barcelona: Centre d'estudis del patrimoni arqueológic de la prehistoria.

$\rightarrow$ d'Errico, Francesco, and Maria F. Sánchez-Goñi. 2003. Neandertal extinction and the millennial scale climatic variability of OIS 3. Quaternary Science Reviews 22:769-788.

$\rightarrow$ Dibble, Harold L. 1987. The interpretation of Middle Paleolithic scraper morphology. American Antiquity 52:109-117.

Dibble, Harold L., and Nicholas Rolland. 1992. On assemblage variability in the Middle Paleolithic of western Europe: history, perspectives, and a new synthesis. In The Middle Paleolithic: adaptation, behaviour and variability. Harold L. Dibble and Paul Mellars, eds. Pp. 1-28. Philadelphia: University Museum, University of Philadelphia.

Falguères, Christophe, Y. Yokoyama, and Á. Arrizabalaga. 2005. La geocronología del yacimiento pleistocénico de Lezetxiki (Arrasate, País Vasco): crítica de las dataciones existentes y algunas nuevas aportaciones. Munibe 57. 93-106.

Fernández Peris, Josep. 2007. La Cova del Bolomor (Tavernes de la Valldigna, Valencia): las industrias del Pleistoceno medio en el ámbito del Mediterráneo peninsular. Serie de Trabajos Varios, no. 108. Valencia: Servicio de Investigación Prehistórica, Diputación Provincial de València.

Fernández Peris, Josep, V. Barciela, R. Blasco, F. Cuartero, and P. Sañudo. 2008. El Paleolítico Medio en el territorio valenciano y la variabilidad tecnoeconómica de la Cova del Bolomor. In Variabilidad técnica del Paleolitico Medio en el sudoeste de Europa, vol. 14. Rafael Mora, Jorge MartínezMoreno, Ignacio de la Torre, and J. Casanova, eds. Pp. 141-169. Barcelona: Treballs d'Arqueologia.

$\rightarrow$ Finlayson, Clive, F. Giles, J. Rodríguez-Vidal, D. A. Fa, J. M. Gutiérrez, A. S. Pérez, G. Finlayson, et al. 2006. Late survival of Neanderthals at the southernmost extreme of Europe. Nature 443:850-853.

Freeman, Leslie G. 1966. The nature of Mousterian facies in Cantabrian Spain. American Anthropologist 68:230-237.

Galván, Bertila, C. M. Hernández, M. I. Francisco, and A. Rodríguez. 2006. Datos para la caracterización del final del musteriense en los valles de Alcoi. In En el centenario de la cueva de El Castillo: el ocaso de los Neandertales. Victoria Cabrera, Federico Bernaldo de Quirós, and Jose M. Maíllo, eds Pp. 127-141. Madrid: Centro Asociado a la Universidad Nacional de Educación a Distancia en Cantabria.

Gamble, C. 1986. The Palaeolithic settlement of Europe. Cambridge: Cambridge University Press.

Geneste, Jean-Michel. 1985. Analyse lithique d'industries moustériennes du Périgord: une approche technologique du comportement des groupes humains au Paléolitique Moyen. Bordeaux: PhD dissertation, Université de Bordeaux I.

- 1990. Développement des sytèmes de production lithique au cours du Paléolithique moyen en Aquitaine septentrionale. In Paléolithique moyen et récent et Paléolithique supérieur ancien en Europe: ruptures et transitions: examen critique des documents archéologiques: actes $d u$ colloque international de Nemours, 9-10 mai 1988. Catherine Farizy, ed. Pp. 203-213. Nemours: Mémoires du Musée de Préhistoire d'Ile-de-France.

González Urquijo, Jesus E., J. J. Ibáñez, J. Ríos, and L. Bourguignon. 2006. Aportes de las nuevas excavaciones en Axlor sobre el final del Paleolítici Medio. In En el centenario de la cueva de El Castillo: el ocaso de los Neandertales. Victoria Cabrera, Federico Bernaldo de Quirós, and Jose M. Maíllo, eds. Pp. 269-289. Madrid: Centro Asociado a la Universidad Nacional de Educación a Distancia en Cantabria.

Goren-Inbar, Naama, and Anna Belfer-Cohen. 1998. The technological abilities of the Levantine Mousterians: cultural and mental capacities. In Nean- dertals and modern humans in western Asia. Takeru Akazawa, Kenichi Aoki, and Ofer Bar-Yosef, eds. Pp. 205-221. New York: Plenum.

Hovers, Erella, and Anna Belfer-Cohen. 2013. On variability and complexity: lessons from the Levantine Middle Paleolithic record. Current Anthropology 54(suppl. 8):S337-S357.

Jaubert, Jacques. 2011. Archéoséquences du Paléolithique moyen du sud-ouest de la France: quel bilan un quart de siècle après François Bordes? In François Bordes et la préhistoire. François Delpech and Jacques Jaubert, eds. Pp. 235253. Paris: Editions du Comité des Travaux Historiques et Scientifiques.

Kuhn, Steven L. 1995. Mousterian lithic technology: an ecological perspective. Princeton, NJ: Princeton University Press.

- 2006. Trajectories of change in the Middle Paleolithic of Italy. In Transitions before the transition: evolution and stability in the Middle Paleolithic and Middle Stone Age. Erella Hovers and Steven L. Kuhn, eds. Pp. 109-120. New York: Springer.

Kuhn, Steven L., and Erella Hovers. 2006. General introduction. In Transitions before the transition: evolution and stability in the Middle Paleolithic and Middle Stone Age. Erella Hovers and Steven L. Kuhn, eds. Pp. 1-11. New York: Springer.

Laville, Henri. 1973. The relative position of Mousterian industries in the climatic chronology of the Early Wurm in the Perigord. World Archaeology 4:323-329.

Manzano, Ivan, J. Baena, A. Lázaro, D. Martín, L. Dapena, M. Roca, and E. Moreno. 2005. Análisis de los recursos líticos en la Cueva del Esquilleu: gestión y comportamiento durante el Musteriense (Comarca de la Liébana, Occidente de Cantabria). In Neandertales cantábricos: estado de la cuestión. Jose A. Lasheras and Ramon Montes, eds. Pp. 285-300. Monografías Nacional y Centro de Investigación de Altamira 20. Madrid: Ministerio de Cultura, Subdirección General de Publicaciones, Información y Documentación.

Maroto, Julia, M. Vaquero, A. Arrizabalaga, J. Baena, E. Baquedano, J. Jordá, R. Julia, et al. 2012. Current issues in Late Middle Palaeolithic chronology: new assessments from northern Iberia. Quaternary International 247:1525 .

Martínez-Moreno, Jorge, Ignacio de la Torre, Rafael Mora, and Joel Casanova. 2010. Technical variability and changes in the pattern of settlement at Roca dels Bous (southeastern Pre-Pyrenees, Spain). In Settlement dynamics of the Middle Paleolithic and Middle Stone Age, vol. 3. Nicholas J. Conard and Anne Delagnes, eds. Pp. 485-507. Tübingen: Kerns.

Martínez-Moreno, Jorge, Rafael Mora, and Ignacio de la Torre. 2004. Methodological approach for understanding Middle Palaeolithic settlement dynamics at La Roca dels Bous (Noguera, Catalunya, Northeast Spain). In Settlement dynamics of the Middle Paleolithic and Middle Stone Age, vol. 2. Nicholas J. Conard, ed. Pp. 393-413. Tübingen: Kerns.

$\rightarrow$ 2010. The Middle-to-Upper Palaeolithic transition in Cova Gran (Catalonia, Spain) and the extinction of Neanderthals in the Iberian Peninsula. Journal of Human Evolution 58:211-226.

Mellars, Paul. 1969. The chronology of Mousterian industries in the Perigord region of south-west France. Proceedings of the Prehistoric Society 35:134171.

Moncel, Marie-Hélène, and Camille Daujeard. 2012. The variability of the Middle Palaeolithic on the right bank of the Middle Rhône Valley (southeast France): technical traditions or functional choices? Quaternary International 247:103-124.

Moncel, Marie-Hélène, Anne-Marie Moigne, Youssef Sam, and Jean Combier. 2011. The emergence of Neanderthal technical behavior: new evidence from Orgnac 3 (level 1, MIS 8), southeastern France. Current Anthropology 52: $37-75$.

Montes, Ramon, and Juan Sanguino. 2005. Nuevos datos para el conocimiento del Paleolítico Medio en el centro de la Región Cantábrica: la Cueva de Covalejos. In Neandertales cantábricos: estado de la cuestión. J. A. Lasheras and R. Montes, eds. Pp. 489-538. Monografías Nacional y Centro de Investigación de Altamira 20. Madrid: Ministerio de Cultura, Subdirección General de Publicaciones, Información y Documentación.

Mora, Rafael. 1988. El Paleolítico Medio en Catalunya. PhD dissertation, Universidad de Barcelona.

Mora, Rafael, A. Benito-Calvo, Jorge Martínez-Moreno, P. González, and I. de la Torre. 2011. Chrono-stratigraphy of the Upper Pleistocene and Holocene archaeological sequence in Cova Gran (south-eastern Pre-Pyrenees, Iberian Peninsula). Journal of Quaternary Science 26:635-644.

Mora, Rafael, Ignacio de la Torre, and Jorge Martínez-Moreno. 2004. Middle Palaeolithic mobility and land use in the southwestern Pyrenees: the example of level 10 in La Roca dels Bous (Noguera, Catalunya, northeast 
Spain). In Settlement dynamics of the Middle Paleolithic and Middle Stone Age, vol. 2. Nicholas J. Conard, ed. Pp. 415-435. Tübingen: Kerns.

$\rightarrow$ Ollé, A., M. Mosquera, X. P. Rodríguez, A. de Lombera-Hermida, M. D. García-Antón, P. García-Medrano, L. Peña, et al. 2013. The early and Middle Pleistocene technological record from Sierra de Atapuerca (Burgos, Spain). Quaternary International 295:138-167.

Pelegrin, Jacques, and Marie Soressi. 2007. Le Châtelperronien et ses rapports avec le Moustérien. In Les Néandertaliens, biologie et cultures. Bernard Vandermeersch and Bruno Maureille, eds. Pp. 283-296. Documents préhistoriques 23. Paris: Éditions du Comité des Travaux Historiques et Scientifiques.

$\rightarrow$ Rink, W. J., H. P. Schwarcz, H. K. Lee, V. Cabrera Valdés, F. Bernaldo di Quirós, and M. Hoyos. 1997. ESR dating of Mousterian levels at El Castillo Cave, Cantabria, Spain. Journal of Archaeological Science 24:593-600.

Ríos, Joseba. 2008. Variabilidad tecnológica en el Paleolítico Medio de los Pirineos Occidentales: una expresión de las dinámicas históricas de las sociedades neandertales. In Variabilidad técnica del Paleolítico Medio en el sudoeste de Europa, vol. 14. Rafael Mora, Jorge Martínez-Moreno, Ignacio de la Torre, and Joel Casanova, eds. Pp. 171-194. Barcelona: Treballs d'Arqueologia.

Ripoll, Eduardo, and Henry de Lumley. 1965. El Paleolítico medio en Cataluña. Ampurias 26/27:1-67.

Rodríguez, Xose P. 2004. Atapuerca y el inicio del Paleolítico medio en Europa. In Arqueología, vol. 4 of Miscelánea en homenaje a Emiliano Aguirre. Pp. 417-431. Zona Arqueología, no. 4. Madrid: Museo Arqueológico Regional.

$\rightarrow$ Santamaría, David, J. Fortea, M. d. l. Rasilla, L. Martínez, E. Martínez, J. C Cañaveras, S. Sánchez-Moral, et al. 2010. The technological and typological behaviour of a Neanderthal group from El Sidrón Cave (Asturias, Spain). Oxford Journal of Archaeology 29:119-148.

Santamaría, David, L. Montes, and P. Utrilla. 2008. Variabilidad técnica del Paleolítico Medio en el valle del Ebro: la Cueva de los Moros I de Gabasa (Peralta de Calasanz, Huesca). In Variabilidad técnica del Paleolitico Medio en el sudoeste de Europa, vol. 14. Rafael Mora, Jorge Martínez-Moreno, Ignacio de la Torre, and Joel Casanova, eds. Pp. 319-339. Barcelona: Treballs d'Arqueologia.

Santonja, Manuel, A. Pérez-González, P. Villa, C. Sesé, E. Soto, R. Mora, V. Eisenmann, and M. Dupré. 2000. El yacimiento paleolítico de Cuesta de la Bajada (Teruel). In $3^{\circ}$ Congresso de Arqueologia Peninsular: Paleolítico do península ibérica, vol. 2. Rodrigo de Balbín, N. Bicho, E. Carbonell, B. Hockett, A. Moure, L. Raposo, M. Santonja, and G. Vega, eds. Pp. 169186. Porto: ADECAP.

Santonja, Manuel, and Paola Villa. 2006. The Acheulean of western Europe. In Axe age: Acheulian toolmaking from quarry to discard. Naama GorenInbar and Gonen Sharon, eds. Pp. 429-478. London: Equinox.

Scott, Becky, and Nick Ashton. 2011. The Early Middle Palaeolithic: the Eu- ropean context. In The ancient human occupation of Britain. Nick Ashton, S. G. Lewis, and C. B. Stringer, eds. Pp. 91-112. Amsterdam: Elsevier.

Slimak, Ludovic. 2008. Faire des outils entre le 50ème et le 35ème millénaire en France méditerranéene: systèmes techniques et évolutions anthropologiques. In Variabilidad técnica del Paleolítico Medio en el sudoeste de Europa vol. 14. Rafael Mora, Jorge Martínez-Moreno, Ignacio de la Torre, and Joel Casanova, eds. Pp. 65-86. Barcelona: Treballs d'Arqueologia.

Soressi, Marie. 2004. From the Mousterian of Acheulian tradition type A to type B: a change in technical tradition, raw material, task, or settlement dynamic? In Settlement dynamics of the Middle Paleolithic and Middle Stone Age, vol. 2. Nicholas J. Conard, ed. Pp. 343-366. Tübingen: Kerns.

Thiébaut, Celine, V. Mourre, P. Chalard, D. Colonge, A. Coudenneau, M. Deschamps, and A. Sacco-Sonador. 2012. Lithic technology of the final Mousterian on both sides of the Pyrenees. Quaternary International 247: 182-198.

Turq, Alain. 2000. Le Moustérien de tradition Acheuléenne. In Paléolithique inférieur et moyen entre Dordogne et Lot. Special issue, Paleo (suppl. 2):244273.

Vaquero, Manuel. 1999. Intrasite spatial organization of lithic production in the Middle Palaeolithic: the evidence of the Abric Romaní (Capellades, Spain). Antiquity 73:493-504.

Vaquero, Manuel, and Eudald Carbonell. 2003. A temporal perspective on the variability of the discoid method in the Iberian Peninsula. In Discoid lithic technology: advances and implications. Marco Peresani, ed. Pp. 67-81. BAR International Series 1120. Oxford: Archaeopress.

Vaquero, Manuel, M. G. Chacón, M. D. García-Antón, B. Gómez de Soler, K. Martínez, and F. Cuartero. 2012. Time and space in the formation of lithic assemblages: the example of Abric Romaní level J. Quaternary International 247:162-181.

Vega, Luis G., P. Cosano, A. Villar, O. Escarpa, and T. Rojas. 1997. Las industrias de la interfase Pleistoceno Medio-Superior en la cueva de la Carihuela (Piñar, Granada). In II Congreso de Arqueología Peninsular, vol. 1. Rodrigo de Balbín and Primitiva Bueno, eds. Pp. 105-118. Zamora, Spain: Fundación Rei Afonso Henriques.

Villaverde, Valentin. 1984. La Cova Negra de Xàtiva y el Musteriense de la región central del Mediterráneo español. Valencia: Diputación Provincial de Valencia.

Zilhão, Joao. 2001. Middle Paleolithic settlement patterns in Portugal. In Settlement dynamics of the Middle Paleolithic and Middle Stone Age, vol. 1. Nicholas J. Conard, ed. Pp. 597-608. Tübingen: Kerns.

. 2006. Chronostratigraphy of the Middle-to-Upper Paleolithic Transition in the Iberian Peninsula. Pyrenae 37:7-84.

2008. The Ebro frontier revisited. In The Mediterranean from 50,000 to 25,000 BP: turning points and new directions. Marta Camps and Carolyn Szmidt, eds. Pp. 293-311. Oxford: Oxbow. 